\title{
土砂生産の活発な流域における 長期的な土砂流出量と河床変動の推定 ESTIMATION OF SEDIMENT DISCHARGE AND RIVER BED VARIATION IN A BASIN WITH HIGH SEDIMENT YIELD
}

\author{
中澤辰哉1・中津川誠 2 \\ Tatsuya NAKAZAWA and Makoto NAKATSUGAWA \\ 1学生会員 室蘭工業大学大学院工学研究科（干050-8585 室蘭市水元町27-1） \\ 2正会員 博士（工学）室蘭工業大学大学院工学研究科（†050-8585 室蘭市水元町27-1）
}

\begin{abstract}
This study aims to estimate sediment discharge and river bed variation based on long-term hydraulic quantities in a basin. For comprehensive sediment management throughout the river basin, it is important to elucidate sediment dynamics, such as the sediment yield from the mountains and sediment transport in the river not only during flood periods but also during normal periods. We formulated non-uniform sediment discharge from the mountainous area by using the long-term hydrologic cycle model. In addition, we performed long-term calculation of river bed variation, using the formulated equations as boundary conditions at the upstream end of the Mu River basin, Hokkaido, a river with high sediment yield. We reproduced the long-term trends of river bed variation and succeeded in estimating the sediment discharge into the estuary.
\end{abstract}

Key Words : sediment discharge, sediment yield, river bed variation, long-term hydrologic cycle

\section{1.はじめに}

山腹斜面，河岸を経て河道へ供給され流下する土 砂は流域管理上，様々な問題を提起する。例えば, ダムや頭首工といった横断構造物は，上流の土砂堆 積により治水，利水に影響を及ぼすとともに，下流 への土砂供給の不足によって環境への影響が懸念さ れる。また，河口域では，上流からの土砂供給が減 少した際，汀線後退や干潟消失が起こり得る。この ような状況を踏まえ, 流域流砂系に対し, 総合的な 土砂管理 ${ }^{1)}$ を行うことが求められている.

そこで，本研究では流域における長期的な水理量 に基づき, 土砂流出量と河床変動を推定し, 流域の 土砂動態を推定することを目的とする。これまで, 流域を所要の目的に応じて分割し，時空間的に土砂 生産や流出過程，もしくはその両者をモデル化した, 砂田 ${ }^{2)}$, 永谷ら ${ }^{3)}$, サニットら ${ }^{4)}$ の研究がある. 以 上の研究は主として流域における土砂動態について, 多大なインパクトを与える大規模出水を対象として いる. 大規模出水によって発生する土砂流出量は影 響の大きさからみて, 大変重要であるが, 他方, 平 常時も含む長期的な土砂流出量を推定することもま た, 総合的な土砂管理を行う上で重要視されるべき である. 特に, 河口域においては平常時における土
砂移動量はそれほど多くは無いが，1年間の総量で 見ると中小洪水一回程度の土砂移動量に相当すると いう点から検討の必要がある占とされる。そこで, 本研究では, 平常時, 出水時を含めた長期的な土砂 動態を取り扱うこととする.

本研究では, 斜面崩壊に伴う土砂生産量の推定を 行った既往の研究成果を活用し, 出水時における山 地上流域の土砂生産量を推定した。さらに，山地上 流域におけるダム堆砂量と潜在的に河道から流出し 得る土砂量の比較を行うことで土砂流出量を推定し， 中下流域を対象として，河床変動計算を行った。具 体的な推定手順は以下の通りである.

1) 山地上流域における長期的な流域水循環を推定 し, 日毎の各水文諸量 (融雪量, 蒸発散量) を推 定し，分布型で流出計算を行う。

2） 筆者ら ${ }^{6}$ が算定した数量化 I 類のパラメータを 用い, 出水時の斜面崩壊に伴う土砂生産量を推 定する。

3） 1)によって得られる各メッシュの計算流量を用

いて河道を流下し得る土砂流出量を算定する。

4) 3)で推定された土砂流出量とダム堆砂量の比較 を行い, 流量を関数とした土砂流出量算定式を 粒径別に定式化する.

5) 中下流域を対象に，4)で得られた土砂流出量を 


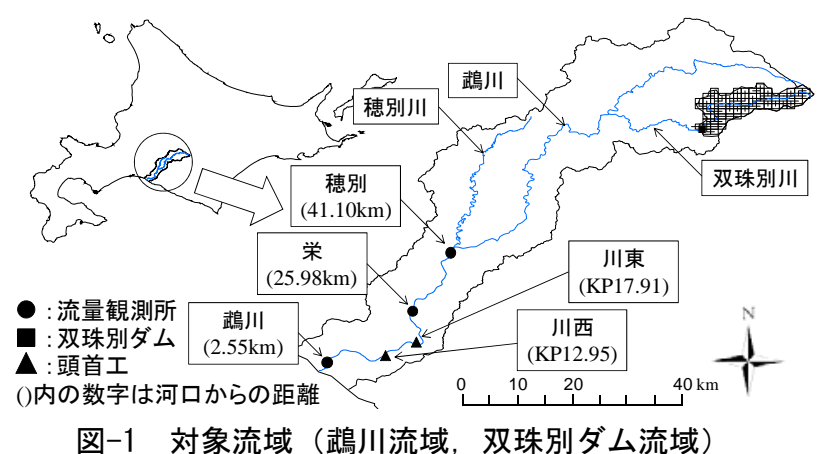

図-1 対象流域（鵡川流域，双珠別ダム流域）

上流端境界条件として, 河床変動計算を実施し, 河口に至る土砂流出量を推定する.

以上により, 長期的な流域の土砂動態を推定する.

\section{2. 対象流域}

対象流域は図-1に示寸北海道胆振地方東部を流れ 太平洋注ぐ一級河川, 鵡川流域（流域面積： $1,270 \mathrm{~km}^{2}$, 幹川流路延長：135km） と上流部の支川 である双珠別川に存在する双珠別ダム流域（流域面 積 : $64 \mathrm{~km}^{2}$ ) である. 武川は急流河川であり, 河床 勾配は上流部で $1 / 150$ 以上, 中流部で約 $1 / 100$

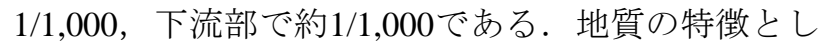
ては，中上流域の一部に蛇紋岩などの変成岩類が分 布し, 地す心゙りや斜面崩壊が生じやすいものとされ る。また, 鵡川河口には干潟が存在し, 渡り鳥の中 継地として機能してきた。河口干潟はかつて広範囲 に広がっていたが，近年は縮小傾向にあり，河口干 潟の保全と再生に向けた取り組みが行われている7 本研究は河口までの土砂流出量を推定するものであ り，干潟保全に資するものと考える。

\section{3. 山地上流域における土砂生産, 土砂流出}

\section{(1) 流域水循環の推定}

\section{a) 推定手法, 条件}

計算期間はデータの蓄積が十分な1998年1月1日〜 2006年12月31日までの9年間である。長期的な流域 水循環の推定には, 谷ら $^{8)}$ の提案するモデルを用 いる. 本モデルは, 熱収支式を基本とし, 蒸発散量 を推定でき, 積雪寒冷地における水循環の重要な要 素である積雪深, 融雪量の変化を考慮している ${ }^{9)}$. さらに, モデルにより得られる蒸発散量, 融雪量お よび観測值として得られる降雨量を用いて, 斜面部 (3段タンクモデル)および河道部(kinematic wave式)に よって構成される流出計算を行う。計算の概略図を 図-2に示寸.

本モデルを図-1に示す約 $1 \mathrm{~km}^{2}$ (3次)メッシュに分 割した双珠別ダム流域に適用し, 日毎に解析するこ とにより, 長期的な流域水循環を定量化した。計算 の基礎データとしては, 流域内外に存在する気象官 署, アメダス, テレメータおよびダム管理所から気 温, 湿度, 降水量, 風速, 積雪深, 日射量, 日照時 間を使用している. 使用した気象データ, 地形デー

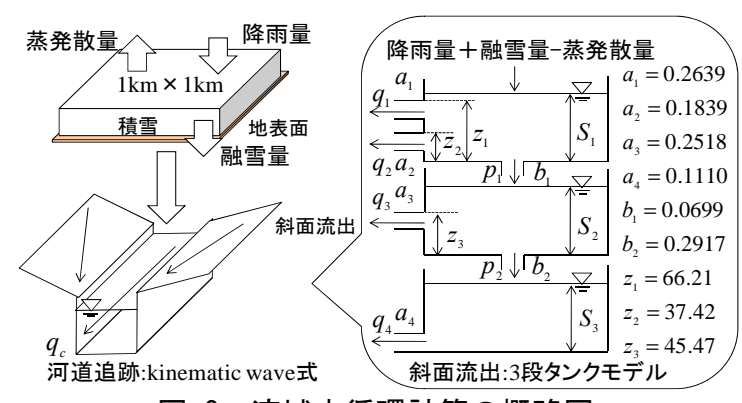

図-2 流域水循環計算の概略図

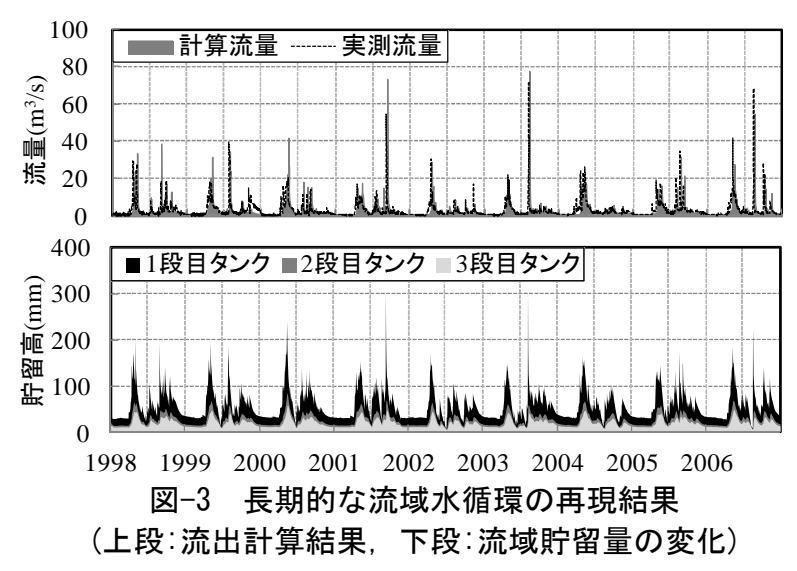

タの詳細は既報后を参照されたい. なお, タンクモ デルのパラメータは中津川ら ${ }^{9)}$ の提案する NewtonRaphson法に基づく数学的最適化手法によって同定 している. 同定期間は2003年8月1日〜10月31日とし， パラメータの探索には双珠別ダム流域における集中 型のタンクモデルを用い, 各メッシュで得られた水 文諸量（降雨, 融雪, 蒸発散) を流域平均して使用 した. 以上により, 得られたパラメータを図-2に示 す. 流域水循環モデルでは, この值を全メッシュに 与え, 斜面流出量を計算する. また, 河道追跡計算 はkinematic wave式に基づく次式8)を用いる.

$$
\frac{\partial q_{c}}{\partial t}+\frac{5}{3} \frac{i_{c}{ }^{0.3} q_{c}{ }^{0.4}}{n_{c}{ }^{0.6} B^{0.4}} \frac{\partial q_{c}}{\partial x}=0
$$

ここで， $q_{c}$ は流量， $n_{c}$ は粗度係数， $i_{c}$ は河道勾配， $B$ は河道幅である。 $n_{c}$ は0.038，icはメッシュ標高差お よび距離から決定し，Bについては流域面積に応じ て変化する山口ら ${ }^{10)}$ の提案式を用いた.

b) 推定結果

図-3には，双珠別ダム流域を対象に以上の手法に よって計算した流量の再現結果および流出計算過程 で得られるタンクモデルの貯留高の変化を示す. 図 によると, 洪水時だけでなく, 平常時の流量も概放 再現できている，なお，決定係数およびNash効率 ${ }^{11}$ による評価では，それぞれ0.76，0.74と若干精度は 低い。しかし, 山地上流域を対象としており, 地上 観測による正確な気象データが存在しない状況での 推定であることに加え, 長期的な流出計算を試みて いることを鑑みれば，概ね十分な再現性が得られた と考えられる. 次に, タンク貯留高の精度検証は実 測データが存在しないため不可能であるが, 流量の 再現性が得られていることから, おおよそ妥当な值 


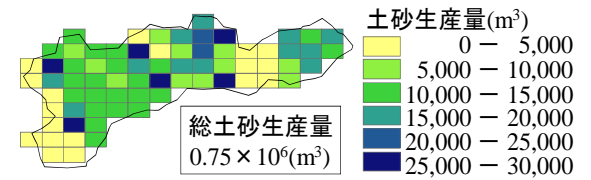

図-4 土砂生産量推定結果

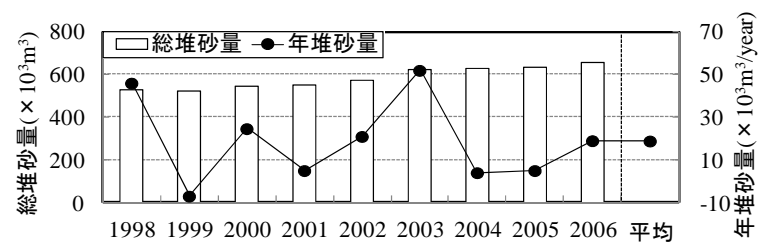

図-5 双珠別ダム堆砂量推移

であることが推測できる，本研究では，以上のタン クモデルによる斜面流出量の計算過程で得られる各 タンクの貯留高を流域貯留量とみなした。

\section{(2) 出水時の斜面崩壊に伴う土砂生産量の推定}

2003年8月 8 日〜 10 日に, 本研究の対象流域である 武川流域に隣接寸る流域である沙流川流域の支川, 額平川流域 $\left(384 \mathrm{~km}^{2}\right)$ において, 大規模な出水が発生

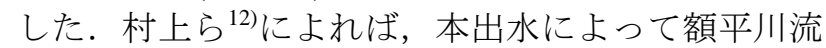
域には4,000箇所を超える新規崩壊地が発生し, 800 万 $\mathrm{m}^{3}$ 超える土砂生産量があったとされる.

筆者ら ${ }^{6}$ は額平川流域を対象として，(1)の手法で 流域貯留量の推定を行った. さらに, 上記の出水事 例について流出計算を行うことで, 時間毎の流域貯 留量の推定を行っている. また，そのようにして得 られた流域貯留量に加え, 降雨量や地形, 地質を考 慮することで斜面崩壊に伴う土砂生産量の推定式を 統計学的推定手法である数量化 I 類を用いて定式化 している. なお，推定に使用したカテゴリ，カテゴ リスコアなど，詳細については既報6)を参照された い.

以上の手法を同様の出水事例を対象に, 双珠別ダ 么流域に適用し，土砂生産量を推定した結果を図-4 に示す. 今, 総土砂生産量 $\left(75\right.$ 万 $\left.\mathrm{m}^{3}\right)$ を流域面積 $\left(64 \mathrm{~km}^{2}\right)$ で除し, 比土砂生産量を算出すると, 約 1.2

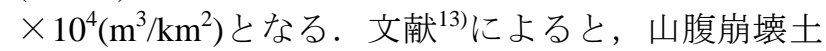
砂と渓床堆積物からなる土石流による土砂流出量の 実績として, $10^{3} \sim 10^{4}\left(\mathrm{~m}^{3} / \mathrm{km}^{2}\right)$ 程度のものが多いと されている.したがって, 本研究によって得られた 值はオーダー的には妥当であるといえる.

また，双珠別ダムにおける堆砂の推移を図-5に示 す. 図-5の左縦軸は総堆砂量を示し, 棒グラフと対 応し, 右縦軸は年堆砂量を示し, 折れ線グラフと対 応している. 図-4に示すように, 対象出水によって 75 万 $\mathrm{m}^{3}$ の総土砂生産量があったことが推定され，一 方, 図-5の 2003年堆砂量は 5.2 万 $\mathrm{m}^{3} / \mathrm{year}$ である. 今, 2003年堆砂量の全てが出水時の土砂生産量で賄われ ていると仮定し, 簡単に総土砂生産量で堆砂量を除 すと, 約 $7 \%$ 土砂生産量が河道を流下し, ダムに 堆砂したと見積もられる.

\section{(3) 土砂流出量の推定}

(2)の検討では, 大規模出水の事例を対象として, 土砂生産量の推定を行ってきた. 本節からは, 平常 時, 出水時を含めた土砂流出量の推定を行う.

\section{a) 推定手法, 条件}

（1）において，双珠別ダム地点の流量を計算する 際に得られる, 各メッシュの河道追跡時の計算流量 を用い，長期間にわたって土砂流出量の推定を行う。 なお，ここで推定を行う土砂流出量には斜面からの 土砂生産量の入力は行っておらず, 河道貯留土砂の みを対象としている. 土砂流出量は, 掃流砂および 浮遊砂に分けて推定を行い, 河床変動計算は実施せ ず，全メッシュで動的平衡条件を仮定して算出する。

掃流砂量は芦田・道上 ${ }^{14)}$ の式を粒径別で表わ寸次 式を用いる。

$$
\frac{q_{b i}}{\sqrt{s g d_{i}^{3}}}=p_{i} 17 \tau_{*_{i}^{\prime 3 / 2}}\left(1-\frac{\tau_{* c i}}{\tau_{*_{i}}}\right)\left(1-\frac{u_{* c i}}{u_{*}}\right)
$$

ここで， $q_{b i}$ は単位幅当たりの掃流砂量， $d_{i}$ は砂粒子 の粒径, $s$ は砂の水中比重, $p_{i}$ は粒径 $d_{i}$ の粒子が河床 に占める割合, $\tau^{\prime} *_{i}$ は無次元有効掃流力, $\tau^{*}$ 快無次元 掃流力, $\tau^{*}$ *i は無次元限界掃流力, $u^{*}$ は摩擦速度, $u^{*} c i$ は限界摩擦速度である。添え字iは粒径別であるこ とを示す。なお， $u^{*} c$ は Egiazaroff ・浅田 ${ }^{15)}$ の式に よって求める.

浮遊砂濃度の計算は動的平衡条件とし, 次式を用 いる.

$$
q_{s u i}-w_{f i} c_{b i}=0
$$

ここで， $q_{s u i l}$ は粒径別浮遊砂の単位面積当たりの河床 からの浮上量, $c b i$ は河床付近の浮遊砂濃度, $w_{f i}$ は粒 径別浮遊砂の沈降速度である。 なお, 河床からの流 砂の浮上量 $q_{\text {sui }}$ は板倉・岸 ${ }^{16)}$, 沖・黒木の式 ${ }^{17)}$ によっ て算出し, $w_{f i}$ はRubey ${ }^{18)}$ の式によって求めた.

水深方向の浮遊砂濃度は指数型の分布式を採用寸 ると，次式で表わされる.

$$
c_{i}=c_{b i} \exp (-\beta \xi)
$$

ここで, $\beta=w_{f f} / \varepsilon, \quad \xi=z / h, z$ は河床からの距離, $h$ は水 深, $\varepsilon$ は水深平均の拡散係数 $\left(=\kappa u^{*} h / 6\right), \kappa$ はカルマン 定数 $(=0.4), c_{i}$ は河床から $z$ の距離における粒子の濃 度である. 水深平均の浮遊砂濃度は式(4)を河床から 水面まで積分することにより次式となる。

$$
<c_{i}>=\frac{c_{b i}}{\beta}[1-\exp (-\beta)]
$$

ここで, $<_{c_{i}}>$ は水深平均の浮遊砂濃度である. 以上 の $<c_{i}>$ に流量を乗じることで浮遊砂量が算出できる. 対象流域は山地上流域であるため, 粒径分布の データが存在しない。 そこで, 中下流域で測定され た河床勾配(1992，1998，2001，2003，2006年)の平 均值および粒径分布の $d_{10}, d_{50}, d_{90}(1992,2001$, 2003，2005年)の平均值を用い, 河床勾配に応じて 粒径を算定する推定式を作成した。推定に用いた データおよび推定式を図-6に示す，以上によって推 定された $d_{10}, d_{50}, d_{90}$ から, 対数正規分布を仮定す ることで，粒径分布を設定する．なお，粒径区分は 最小 $0.01 \mathrm{~mm}$ 最大 $400 \mathrm{~mm}$ までの15分割で設定した. b) 推定結果 

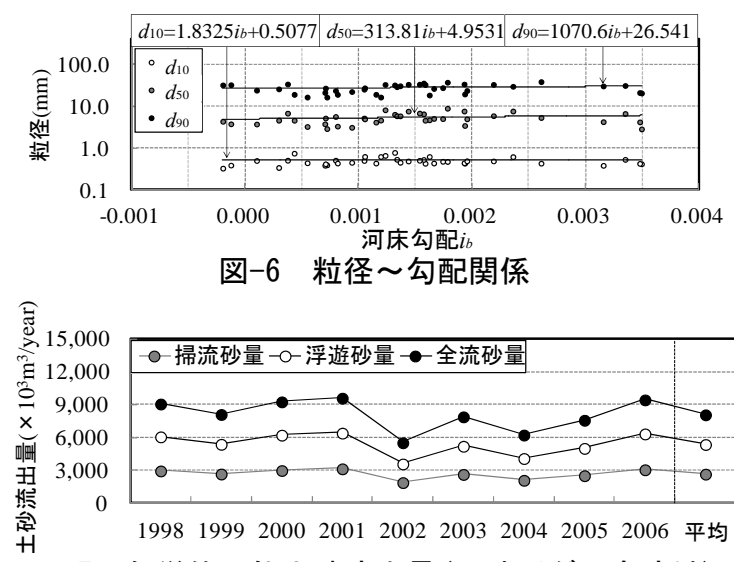

図-7 年単位可能土砂流出量 (双珠別ダム全流域)

以上の掃流砂，浮遊砂式を用い，河道追跡流量を 用いて各メッシュで土砂流出量を算出した。図-7に は各メッシュで推定した土砂流出量を日単位で全 メッシュ合計し，年間で整理を行ったものを示す.

図-7によると，平均年全土砂流出量は 813 万 $\mathrm{m}^{3} /$ year となる。しかし，図-5によると，平均年堆砂量は 1.89 万 $\mathrm{m}^{3} /$ yearである。永谷ら ${ }^{3}$ によれば，平衡浮遊 砂量をそのまま計算に用いた場合には過大評価とな り，低減率を乗じる必要があることが指摘されてお

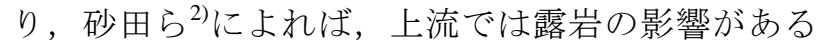
ため流送土砂を制限する必要があるとされている. 本手法による推定では, 上記の研究2),3)で行われて いるような低減率や制限係数を用いた土砂流出量の 補正を行っていないことから，過大となったと考え られる。また, 土砂流出量が過大となった他の原因 として， ウォッシュロードの形態を取るような粒径 に対し, 浮遊と沈降のバランスを考慮している点や 粒径の設定について，下流河道の粒径〜勾配関係 (図-6)を適用しており，山地上流域においてはその ほとんどを外挿的に決定してしまうことから，実態 の粒径分布を適切に表現できていない可能性がある 点が考えられる.

しかしながら, 今回推定された土砂流出量は水理 量に基づいて決定される土砂流出量であるとみな寸 ことができる。つまり，潜在的に河道を流出し得る 土砂量(以下, 可能土砂流出量)である. 今, 大雑把 な仮定として, 可能土砂流出量の全てがダムに堆砂 したものと考えると, 平均年堆砂量を平均年可能土 砂流出量で除すことで， $\alpha=0.232(\%)$ という割合が算 出される。これは, 可能土砂流出量をオーダー的に 実態の土砂流出量に合うように補正することが可能 な係数となる.

可能土砂流出量の計算は日毎に各メッシュの掃流 砂，浮遊砂を対象に粒径別で行っている．図-8には 粒径別に推定された可能土砂流出量を流域面積で除 した比可能土砂流出量と双珠別ダム地点の比流量と の関係を示す. 以上により得られた粒径別比可能土 砂流出量に前述の補正係数 $\alpha$ を乗じることで，比流 量から比土砂流出量を推定することができる。なお, 補正係数 $\alpha$ は年単位という長期的な土砂流出量〜堆 砂量関係から得られたものであるため，この関係が

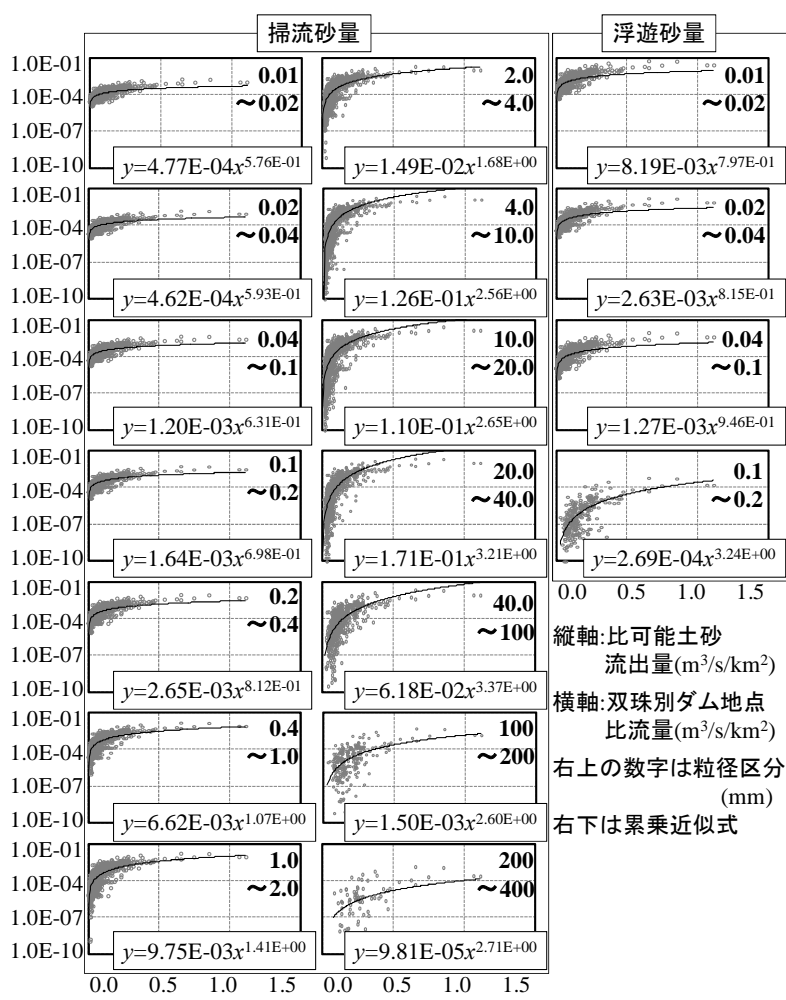

図-8 粒径別比可能土砂流出量～比流量関係

短期的に成立するかは検証されていない，本研究で は便宜的にその関係が成立するものとして後の議論 を進めていくこととなるが，今後いくつかの流域に 同様の手法を用いることで，その汎用性や適用性を 検証することが必要であると考える。

\section{4. 中下流域における河床変動計算}

本章では，3（3）で得られた関係式を用い，中下 流域を対象として河床変動計算を行う。

\section{（1）計算手法，条件}

流れの計算は，マニング則を用いた不等流の方程 式を幅広矩形断面で考慮した次式を用いる.

$$
\frac{\partial H}{\partial x}+\frac{Q^{2}}{2 g} \frac{\partial}{\partial x}\left(\frac{1}{B^{2} h^{2}}\right)+\frac{Q^{2} n^{2}}{B^{2} h^{10 / 3}}=0
$$

ここで, $H$ は水位, $B$ は川幅, $h$ は水深, $Q$ は流量, $g$ は重力加速度, $n$ は粗度係数 $(=0.03)$ である.

掃流砂量式は式(2), 浮遊砂の浮上量式は板倉・岸 16)の式を用いる。 また, 浮遊砂濃度の計算は次式で 表わされる浮遊砂濃度連続式を用いる.

$$
\frac{\partial}{\partial t}\left(<c_{i}>h\right)+\frac{1}{B} \frac{\partial\left(Q<c_{i}>\right)}{\partial x}=q_{s i i}-w_{{ }_{f i}} c_{b i}(7)
$$

河床変動計算では, 次式で表わされる粒径別流砂 の連続式を用いる ${ }^{19)}$.

$$
\delta \frac{\partial p_{i}}{\partial t}+p_{i}^{*} \frac{\partial \eta}{\partial t}+\frac{1}{1-\lambda}\left[\frac{1}{B} \frac{\partial\left(q_{b i} B\right)}{\partial x}+q_{s u i}-w_{f i} c_{b i}\right]=0 \text { (8) }
$$

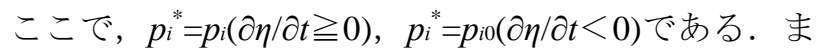
た, $p_{i}$ は流砂中における粒度構成, $p_{i 0}$ は原河床の粒 度構成， $\eta$ は河床高, $\delta$ は交換層の厚さ(ここでは0.1

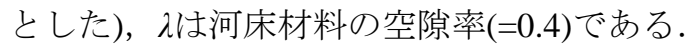


全流砂の連続式は全粒径の流砂の交換を考慮し， 次式で表わされる.

$$
\frac{\partial \eta}{\partial t}+\frac{1}{1-\lambda}\left[\frac{1}{B} \frac{\partial \sum_{i}\left(q_{b i} B\right)}{\partial x}+\sum_{i}\left(q_{s u i}-w_{f i} c_{b i}\right)\right]=0(9)
$$

計算期間は1998年1月1日〜2006年12月31日である。 計算区間はKP0.4(以下，河口)～穂別観測所(以下， 上流端)までである。河道断面は低水路満杯流量を 考慮し, 低水路矩形近似単断面を使用し，川幅や粗 度係数も現地測量結果を使用する. 河床高は1998年 の平均河床高(KP0.2間隔)を初期条件とし, 河道内の 粒径分布は1992年(KP1.0間隔)のデータを当該断面と その前後2断面ずつに同一の值を設定した。計算時 間間隔はCFL条件により決定した。断面間隔は $\mathrm{KP} 0.2$ 間隔(約 $200 \mathrm{~m})$ を基本として設定するが，図-1 に示寸ように下流域に川西頭首工(KP12.95), 川東頭 首工(KP17.91)の2基の頭首工が存在することで流れ の計算が不安定になる。そこで，頭首工付近には内 挿断面を前後3断面設定し, 固定点として取り扱う。 流量は縦断変化を考慮するため，清水 ${ }^{20)}$ の方法を参 考とし，計算区間内の流量観測所における平均年最 大流量を用いた累乗近似式の係数から，次式で表わ される鵡川観測所の流量データを与えることで，任 意断面の流量を算定できる推定式を用いた.

$$
Q=Q_{m} \exp [-0.00979(L-2.55)]
$$

ここで， $Q_{m}$ は鵡川観測所の流量， $Q$ は任意断面の流 量, Lは河口から任意断面までの距離 $(\mathrm{km})$ である. 下流端の境界条件は流域近傍の苫小牧東港で観測さ れた潮位を使用寸る。上流端の境界条件には，前述 の粒径別比土砂流出量～比流量関係式から土砂を流 出させる場合(以下，土砂流出推定法)と上流端を動 的平衡条件として計算する場合(以下，動的平衡法) の2通りの計算を行い，設定方法の違いによる結果 の比較を行う。

\section{(2) 河床変動計算結果}

河床変動計算の精度比較には，2002年1月，2003 年12月，2006年12月の平均河床高の実測データを用 いる. 図-9には，精度比較時の実測值に対するそれ ぞれの計算値の誤差(計算值-実測值)を示す。図によ ると，全体的な変動形態はどちらも同じ傾向を示し ている。また，いずれもKP30より上流部では，土 砂流出推定法の方が動的平衡法に比べ堆積が小さく 実測值に近い傾向を示している。次に，全体的な河 床変動計算結果の精度を確認するため, 次式で表わ されるRMSEを用いて評価を行う。

$$
R M S E=\sqrt{\frac{\sum\left(Z_{o}-Z_{s}\right)^{2}}{N}}
$$

ここで，Zoは実測平均河床高，Zsは計算平均河床高, $N$ は断面データ数である。表-1には精度比較時の RMSEおよびそれらの平均值を示す，表によると， 動的平衡法と土砂流出推定法の平均RMSEは0.72(m), 0.62(m)であり, 土砂流出推定法は動的平衡法に比べ, RMSEで0.1(m)小さく推定できた.

$$
\text { ところで，河床変動計算では各断面において掃流 }
$$

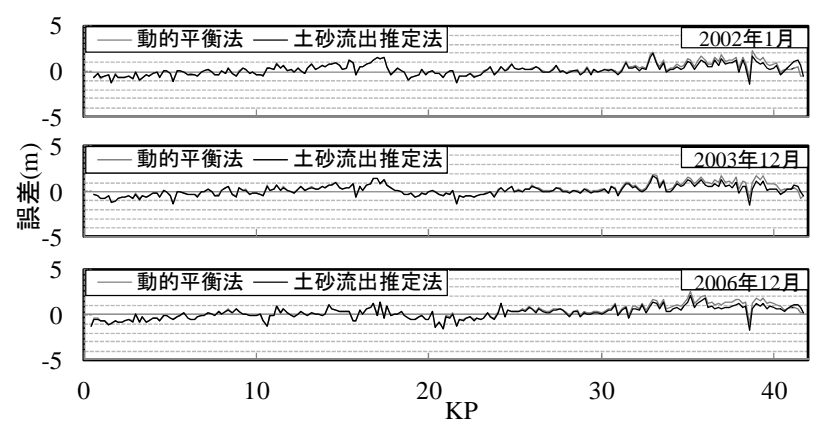

図-9＼cjkstart河床変動計算結果の誤差

表-1 河床変動計算の誤差

\begin{tabular}{|l|c|c|c|c|}
\hline \multicolumn{1}{|c|}{$\mathrm{RMSE}(\mathrm{m})$} & 2002年1月 & 2003年12月 & 2006年12月 & 平均 \\
\hline 動的平衡法 & 0.69 & 0.68 & 0.79 & 0.72 \\
\hline 土砂流出推定法 & 0.62 & 0.57 & 0.67 & 0.62 \\
\hline
\end{tabular}

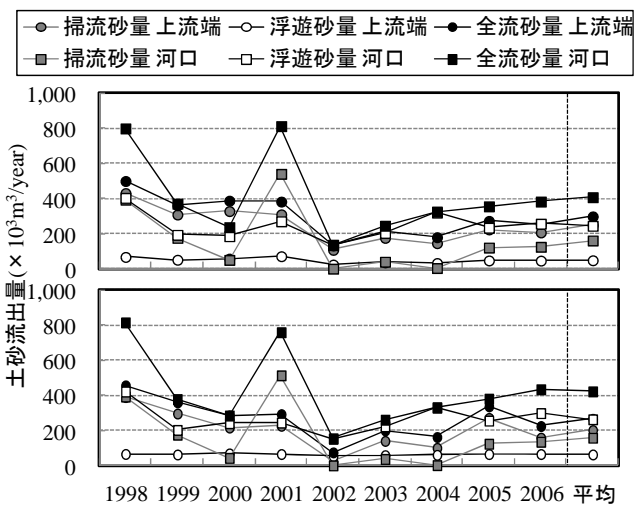

図-10 年単位土砂流出量計算結果

(上段:動的平衡法 下段:土砂流出推定法)

表-2 出水時土砂流出量の年間に占める割合 (河口)

\begin{tabular}{|l|c|c|c|}
\hline 出水時/年単位×100(\%) & $\begin{array}{c}\text { 2001年 } \\
\text { 9月11日 13日 }\end{array}$ & $\begin{array}{c}\text { 2003年 } \\
\text { 8月8日 10日 }\end{array}$ & $\begin{array}{c}\text { 2006年 } \\
\text { 8月 18日 19日 }\end{array}$ \\
\hline 動的平衡法 $(\%)$ & 78 & 62 & 64 \\
\hline 土砂流出推定法 $(\%)$ & 75 & 51 & 62 \\
\hline \hline 鵡川観測所最大流量 $\left(\mathrm{m}^{3} / \mathrm{s}\right)$ & 2,773 & 2,588 & 2,194 \\
\hline
\end{tabular}

砂，浮遊砂の土砂流出量が計算される．図-10には 上流端の境界条件をそれぞれの手法で設定した場合 の土砂流出量および河口での土砂流出量の計算值を 年単位で整理したもの示寸. 図によると, どちらの 手法もともに同様の変動傾向を示している. なお, 平均年全土砂流出量については，上流端で約 30 万 $\mathrm{m}^{3}$, 河口で約 40 万 $\mathrm{m}^{3}$ となり, 土砂収支の差は約 10 万 $\mathrm{m}^{3}$ で あると見積もられる。これは下流河道部の残流域か らの土砂流入量と推測される。計算区間の残流域は 約 $321 \mathrm{~km}^{2}$ であり，上流端の流域面積の約 $1 / 3$ である。 そこで，簡単に上流端での土砂流出量を比流量配分 で考慮すると約 $10 万 \mathrm{~m}^{3}$ となり概ね一致する。残流域 の土砂流入量を考慮した河床変動計算は今後の課題 としたい。また，表-2には河口における，解析期間 中に発生した「主な出水時の土砂流出量」の「各年 の年単位土砂流出量」に占める割合および出水時の 武鳥川観測所最大流量を示寸. 表によると, 出水時土 砂流出量が年単位土砂流出量における51〜 78\%を占 めることがわかる. つまり，その年の平常時土砂流 出量は22〜 49\%を占め, 割合から見てもその量は無 


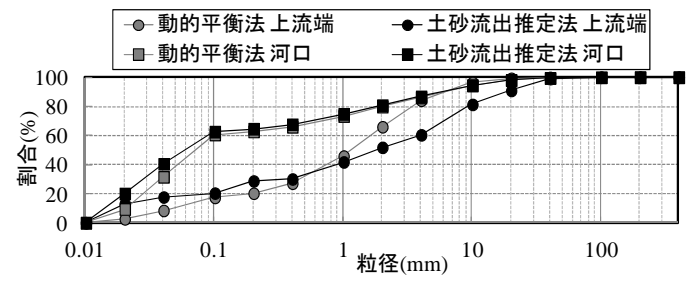

図-11 平均年全土砂流出量の粒径割合

視できないものであると考える.

さらに，図-11にはそれぞれの平均年全土砂流出 量の粒径別の割合を示す. 図によると, どちらの手 法も河口での分布は類似しているが，上流端では土 砂流出推定法の方がシルトの割合が若干大きい傾向 を示した。 また，どちらの手法も上流端に比べ河口 の方がシルト〜砂の割合が大きく，砅〜石の割合が 小さいことから，実河川の質的な一般的傾向も概及 再現できたと考える.

\section{5. まとめ}

本報告において得られた結果を以下にまとめる.

1) 山地上流域である双珠別ダム流域において, 2003年8月 8日〜10日に発生した出水を対象とし て, 斜面崩壊に伴う土砂生産量の推定を行い, 流域全体で約75万 $\mathrm{m}^{3}$ の総土砂生産量があったと 推定された。また，その約 $7 \%$ が河道を流下し， ダムに堆砂したと見積もられた。

2) 双珠別ダム流域における水理量に基づき，可能 土砂流出量の推定を行い, 平均年全土砂流出量 は813万 $\mathrm{m}^{3}$ と見積もられた。 さらに，それをダ 么堆砂量と比較することで得られる補正係数を 用い，粒径別の土砂流出量算定式を定式化した。

3) 中下流部の河床変動計算を行った結果, 土砂流 出推定法は動的平衡法よりもRMSEで0.1(m)だ け小さく再現できた。また，年単位では上流端 での土砂流出量は約 30 万 $\mathrm{m}^{3}$, 河口での土砂流出 量は約 40 万 $\mathrm{m}^{3}$ と推定され, 残流域からの土砂流 入量によって，その収支を考慮できることが示 された.さらに, 河口における土砂流出量は年 単位でみると出水時に $51 \sim 78 \%$ を占め, 平常時 は22〜49\%を占めることが示された.また，ど ちらの手法も上流端に比べ河口の方がシルト〜 砂の割合が大きく, 碩〜石の割合が小さくなり， 実河川の質的な一般的傾向の再現ができた.

ただし，本研究で用いられた諸手法はその適用性， 汎用性が十分に検討されていない点がいくつか存在 する. これらの点に関しては今後, 複数の流域での 適用を踏まえ，検証する必要があると考える。

本研究で得られた成果を河口域における土砂動態 の推定に活用し, 健全な流砂環境の実現や河口の干 潟保全の取り組みに役立てていきたい.

謝辞：本研究の一部は国土交通省河川砂防技術研究 開発公募（地域課題分野）の助成を受けて行ったも のである、また，本論文をまとめるにあたり国土交
通省北海道開発局室蘭開発建設部, 気象庁に資料提 供等でご協力いただいた。ここに記して謝意を表す。

\section{参考文献}

1）河川審議会総合土砂管理小委員会：「流砂系の総合 的な土砂管理に向けて」報告, 1998.

2）砂田憲吾, 塩沢みゆき, 加藤克夫: 大規模土砂生産に よる流域水系河床変化の伝播特性について, 水工学 論文集, 第40巻, pp.843-848, 1996.

3) 永谷言, 高田康史, 小沢和也, 寶馨, 佐山敬洋: 豪雨 時の斜面崩壊過程を考慮した分布型土砂流出モデル に関する研究，河川技術論文集，第15巻，pp.429-434， 2009.

4) サニットウォンサ, 清水康行, 岩井聖: 流域全体系に おける土砂動態のモデル化の試み：河道形状・土地 利用変遷に関寸る基礎的検討, 水文・水資源学会誌, 第17巻6号, pp593-606, 2004.

5) 末次忠司, 日下部隆昭, 坊野聡子: 土砂管理施策の ためのキーノート〜土砂動態の時空間的不連続性 を考慮した流域管理に向けて〜，国土技術総合研究 所資料, No.231, 2005.

6) 中澤辰哉, 中津川誠, 臼谷友秀: 流域の湿潤状態の分 布を考慮した土砂生産量の推定, 水工学論文集, 第 56巻, pp.901-906, 2012.

7) 北海道開発局: 鵡川水系河川整備計画, 2009.

8）臼谷友秀, 工藤啓介, 中津川誠: 石狩川における水循 環の定量化について, 水工学論文集, 第49巻, pp.229234, 2005.

9) 中津川誠, 濱原能成, 星清: 積雪変化を考慮した長期 流出計算, 水工学論文集, 第47巻, pp.58-63, 2003.

10) 山口甲, 新庄興, 三田村一弘, 上野順也: 豊平川の生 産土砂について, 土木学会北海道支部論文報告集, 第55号(B), pp.268-271, 1998.

11) Nash, J.E. and Sutcliffe, J.V.: River flow forecasting through conceptual models. Part1. A discussion of principles, J. of Hydrol., Vol.10, pp.282-290, 1970.

12）土木学会水工学委員会: 平成15年台風10号北海道豪 雨災害調查団報告書, pp.1-95, 2004.

13）社団法人 土木学会: 水理公式集[平成11年度版], 丸 善(株), pp.145-146, 2000.

14）芦田和男, 道上正規: 移動床流れの抵抗と掃流砂量 に関寸る基礎的研究，土木学会論文報告集，第206号， pp.59-69. 1972.

15）浅田宏: 山地河川の流砂量と貯水池の堆砂過程に関 寸る研究, 電力中央研究所報告, No.2. 1976.

16) Itakura, T. and Kishi, T.: Open channel flow with suspended sediments, Proc. of ASCE, HY8, pp.1325-1343, 1980.

17) 沖健, 黒木幹男: 混合床上の浮遊砂量の算定式の検 討, 土木学会第 40 回年次学術講演会講演概要集, pp.415-416, 1985.

18) Rubey, W. W.: Settling velocity of gravel, sand and silt particles. Amer. Jour. Sci., 25, pp.325-338, 1933.

19）平野宗夫: Armoringをともなう河床低下について，土 木学会論文報告集, 第195号, pp.55-65, 1971.

20) 清水康行: 沖積河川の縦断形と河床材料分布系の形 成について, 土木学会論文集, No.521/II-32, pp.69-78, 1995.

(2012. 9. 30受付) 